\title{
VERTEBRATE REMAINS FROM THE ROTZO FORMATION (LOWER JURASSIC, TRENTO PLATFORM, ITALY): PRELIMINARY NOTE
}

\author{
Fabio Franceschi ${ }^{1} \oplus \&$ Massimo Bernardi ${ }^{2}$ (두 \\ ${ }^{1}$ Dipartimento di Scienze della Terra "A. Desio", Università degli Studi di Milano, Milan, Italy; \\ ${ }^{2}$ MUSE, Museo delle Scienze di Trento, Trento, Italy.
}

\author{
KEYWORDS: \\ Early Jurassic; \\ Trento Platform; \\ Rotzo Formation; \\ Teleosauridae; \\ Hybodontidae.
}

\section{Bullet-Points Abstract}

- The Rotzo formation is a thick fossiliferous marine-lagoon succession of North Italy.

- Vertebrate fossil record is poorly known from this Formation.

- After the late 90's no study focused on the vertebrates of this area, but new specimens have been collected.

- A master thesis is in progress to study the Rotzo Formation vertebrate fauna.

\section{InTRoduction \& GeOlogical SETting}

Several Jurassic outcrops are reported from Sette Comuni Plateau territory, in the Trentino-Alto Adige region (North-East Italy). These outcrops belong to the Trento Platform, more precisely to the Calcari Grigi Group: a thick marine-lagoon succession.

During the Sinemurian-Pliensbachian (Posenato \& Masetti, 2012) the central-western sector of the Trento Platform evolved into a lagoon environment (Bosellini \& Broglio Loriga, 1971) or ramp-lagoon setting (Masetti et al., 1998), where the Rotzo Formation was deposited. This is the topmost unit of the Calcari Grigi Group, known also for the rich faunistic and floral content. This formation is typified by coarsening and thickening upward subtidal facies with a characteristic asymmetrical profile (Masetti et al., 1998).

\section{INVERTEBRATE AND FLORAL FOSSIL RECORD}

The Rotzo Formation is characterized by the occurrence of bivalves as species of the genera Cochlerites, Gervillioperna, Lithioperna, Mytiloperna and Pseudopachymytilus (Figus, 2012). The "Lithiotis" facies (Broglio Loriga \& Neri, 1976) characterizes the upper part of the Formation. The oligotypic associations of small bivalve Eomiodon are also distinctives and frequently reported in the black-shale levels at the base of each cycle (Bassi et al., 1999). Clusters of the turricolate gastropod Aptixiella and the brachiopod Lychnothyris rotzoana are common. Chaetetes sponges are widespread, echinoderms and corals have been also found. Foraminifera are abundant, with species of the genus Orbitopsella particularly useful for biostratigraphic calibration. The floristic content is also notable (De Zigno, 1856; 1885); the remains of continental plants, occasionally with in situ root systems, suggest that the emerged lands were not too far and there were lenses of fresh or brackish water (Avanzini, 1998). It is worthy to emphasize the recent finding of amber bearing levels (Neri et al., 2016). The high concentration of organic matter in the lower beds suggests an environment with limited water circulation.

\section{VERTEBRATE REMAINS}

Whilst the various publications on plants and invertebrates have given a great contribution to the palaeoecology of the Rotzo Formation, the role of the vertebrate remains has always been rather marginal, mostly because of the relative paucity of the specimens. Several sites with coeval dinosaur tracks (Mietto \& Roghi, 1994; Petti et al., 2011) represent the most documented associations. The remains of marine vertebrates appear less frequently as reported in Avanzini (1998): from the type locality of the Rotzo Formation the remains of Semionotiformes, Pycnodontiformes and a complete specimen of Pholidophoriformes have been reported. Avanzini (1998) described scales attributed to Semionotiformes, articulated specimens of pholidophors and fragmentary remains ascribable to teleosaurid reptiles (Fig. 1).

After the late 90's, no study focused on the vertebrates 


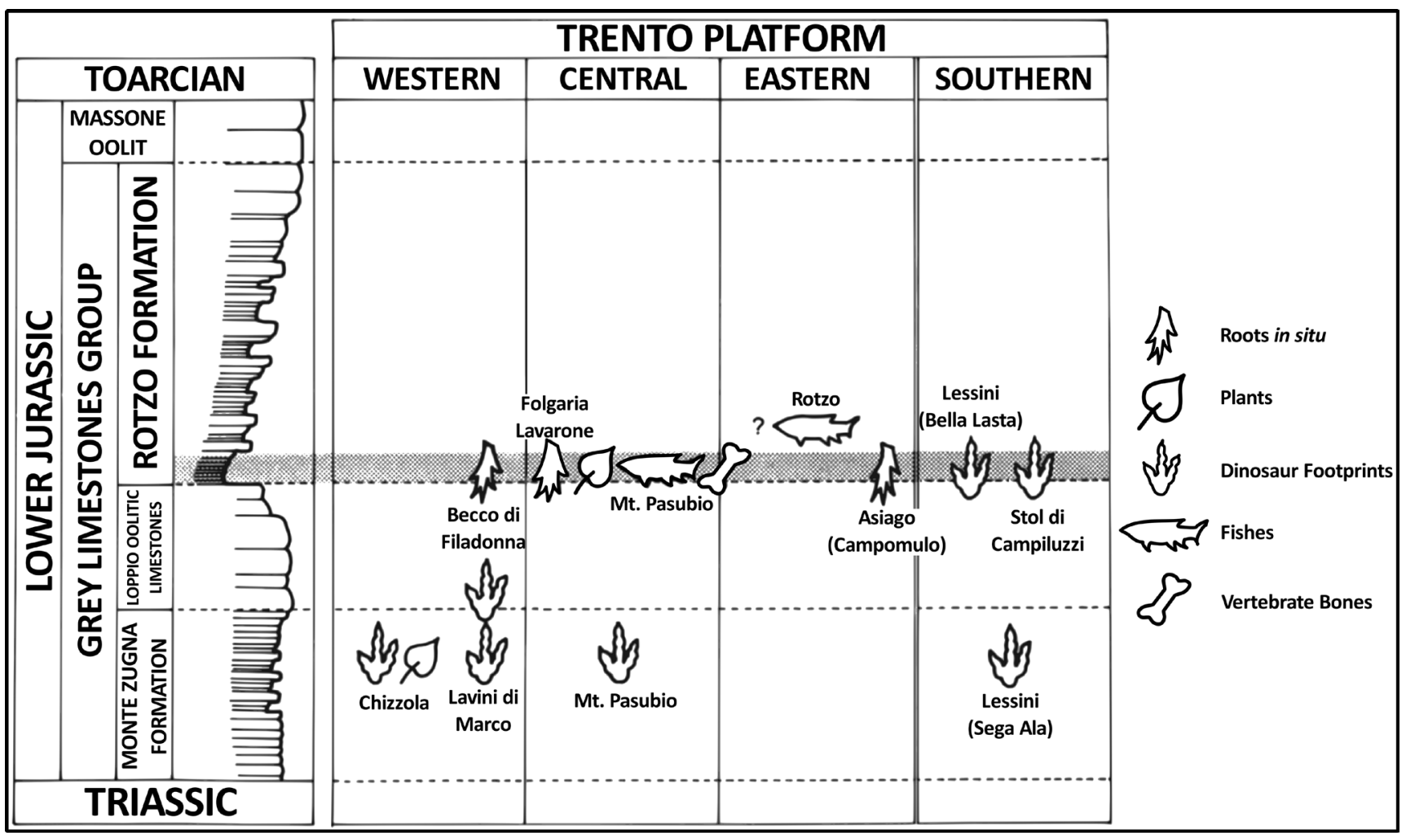

Fig. 1. Stratigraphic framework of the vertebrate bearing levels in the Trento Platform, legend on the right. (edited from Avanzini, 1998).

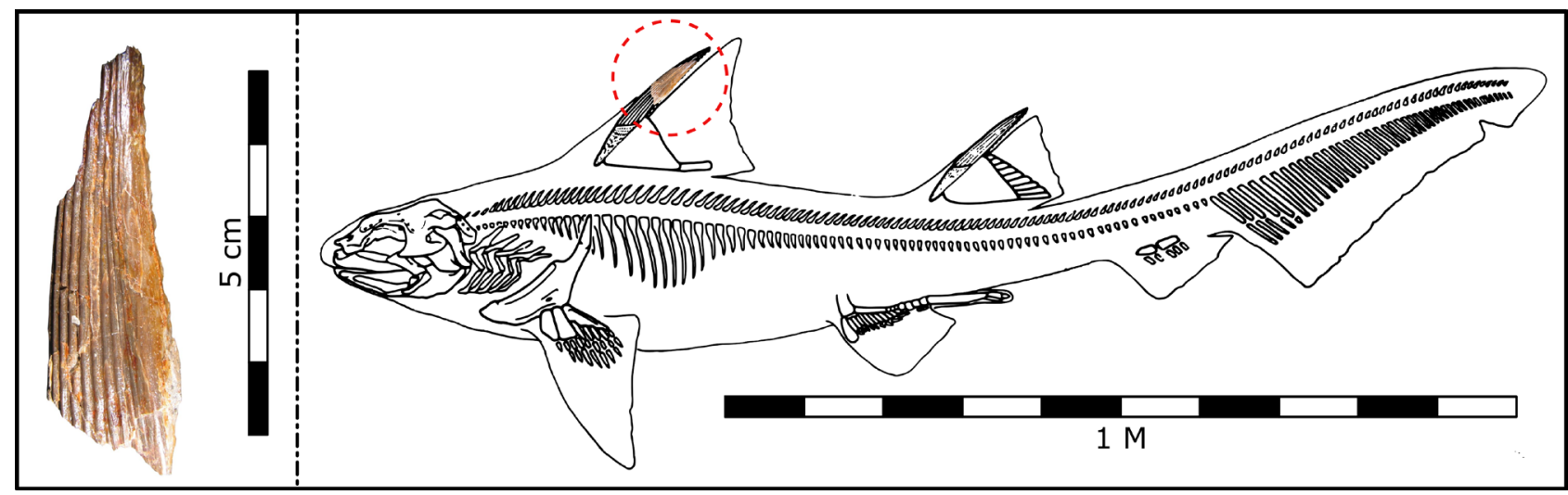

Fig. 2. MTSN 5491, first dorsal fin spine of Hybodus sp., specimen (left) and placement (right) on a reconstruction of Hybodus sp. (Maysey, 1982).

of this area, but the field collection continued. Field campaigns guided by the MUSE (Museo delle Scienze) of Trento and other reports have led to the creation of a collection of vertebrate specimens.

\section{FutURE RESEARCH}

These specimens, now object of a new systematic and stratigraphic study (Franceschi, master thesis, in progress), are attributable to fishes, both bony and cartilaginous, and to reptiles (teleosaurids). Some specimens represent the first report of their groups in this area and await a detailed description (Fig. 2). Current excavations are bringing to light new remains thanks to a careful stratigraphic work that will allow us to understand more of the environmental settings, where tidal flats and lagoons, domain of fish and marine reptiles, coexisted with islands populated by terrestrial vertebrates. 


\section{REFERENCES}

Avanzini M. (1998). Resti di vertebrati dal Giurassico inferiore della Piattaforma di Trento (Italia settentrionale). Nota preliminare. Studi Trentini di Scienze Naturali - Acta Geologica, 73: 75-80.

Bassi D., Boomer I., Fugagnoli A., Loriga C., Posenato R., \& Whatley R.C. (1999). Faunal assemblage and palaeoenvironment of shallow water black shales in the Tonezza area (Calcari Grigi, Early Jurassic, Southern Alps). Annali dell'Università di Ferrara, 8 (2): 1-16.

Bosellini A. \& Broglio Loriga C. (1971). I Calcari Grigi di Rotzo (Giurassico Inferiore, Altopiano di Asiago) e loro inquadramento nella paleogeografia e nella evoluzione tettono-sedimentaria delle prealpi Venete. Annali dell'Università di Ferrara, 5: 1-61.

Broglio Loriga C. \& Neri C. (1976). Aspetti paleobiologici e paleogeografici della facies a "Lithiotis" (Giurese inf.). Rivista Italiana di Paleontologia e Stratigrafia, 82 (4): 651 706.

De Zigno A. (1856). Flora fossilis formationis oolithicae. Tipografia Del Seminario, Padova, 1: 225.

De Zigno A. (1885). Flora fossilis formationis oolithicae. Tipografia Del Seminario, Padova, 1: 203.

Figus B. (2012). La crisi sinemuriana delle piattaforme carbonatiche del Sudalpino orientale. Unpublished $\mathrm{PhD}$ thesis, Università di Ferrara, Ferrara, Italy.
Masetti D., Claps M., Giacometti A., Lodi P. \& Pignatti P. (1998). I Calcari Grigi della Piattaforma di Trento (Lias Inferiore e Medio, Prealpi Venete). Atti Ticinesi di Scienze della Terra, 40: 139-183.

Maisey J.G. (1982). The Anatomy and Interrelationships od Mesozoic Hybodont Sharks. American Museum Novitates, 2724: 1-48.

Mietto P. \& Roghi G. (1994). Nuova segnalazione di impronte di dinosauri nel Giurassico inferiore del Sudalpino: Le piste della Valle di Revolto (Alti Lessini Veronesi). Paleocronache (2): 39-43.

Neri M., Kustatscher E., Roghi G. \& Papazzoni C.A. (2016). Paleobotanical assemblage from the Lower Jurassic amber bearing levels from the Rotzo Formation, Monti Lessini (Venetian Prealps, Northern Italy). "Silicofossil and Palynology Joint Meeting for Advanced Research in Biostratigraphy, Palaeoceanography and Palaeoclimatology", Abstract Volume

Petti F.M., Bernardi M., Todesco R. \& Avanzini M. (2011). Dinosaur footprints as ultimate evidence for a terrestrial environment in the Late Sinemurian Trento carbonate platform. PALAIOS, 26: 601-606.

Posenato R. \& Masetti D. (2012). Environmental control and dynamics of Lower Jurassic bivalve build-ups in the Trento Platform (Southern Alps, Italy). Palaeogeography, Palaeoclimatology, Palaeoecology, 361-362: 1-13. 